\title{
SISTEM PEMANTAUAN GAS H2 DENGAN METODE ELEKTROLISIS
}

\author{
Bambang Suryanto $^{1}$, Ulfa Hanim ${ }^{2}$, Adiansyah ${ }^{3}$ \\ ${ }^{1,2}$ Program Studi Teknologi Elektromedis, STIKES Binalita Sudama \\ ${ }^{3}$ Program Studi Kimia, Fakultas Sain, Teknologi dan Informasi, USM-Indonesia \\ Email: bambangsuryanto1978@gmail.com
}

\begin{abstract}
ABSTRAK
Telah dilakukan penelitian tentang sistem pemantauan gas $\mathrm{H}_{2}$ dengan metode elektrolisis. Penelitian ini dilakukan dalam rangka mencari energi terbarukan ditengah kebutuhan energi dunia yang semakin meningkat sejalan dengan semakin menurunya jumlah minyak bumi dunia. Penelitian ini diharapkan mampu memberikan kontribusi pada energi baru terbarukan. Dalam prosesenya gas hidrogen dapat dihasilkan dari hidrolisis dengan menggunakan TGS 821 dan DAC serta dihubungkan pada perangkat PC dalam proses penelitian ini besar arus yang digunakan adalah $8 \mathrm{~V}, 9 \mathrm{~V}, 10 \mathrm{~V}, 11 \mathrm{~V}$ dan $12 \mathrm{~V}$. hasil penelitian menunjukkan adanya peningkat jumlah hidrogen yang dihasilkan sebanding dengan peningkatan arus yang diberikan dan maksimum pada kuat arus 12 volt. Jumlah hidrogen maksim pada 998,20 ppm dan paling rendah pada $131,60 \mathrm{ppm}$.
\end{abstract}

Kata Kunci: Gas $\mathrm{H}_{2}$; Elektrolis $\mathrm{H}_{2} \mathrm{O}$; Mesin Monitoring; Sensor $\mathrm{H}_{2}$; Diatomik $\mathrm{H}_{2} \mathrm{O}$

\section{PENDAHULUAN}

Indonesia sebagai negara yang terletak di khatulistiwa mempunyai sumber energi yang melimpah, meliputi sumber energi fosil maupun non-fosil. Namun sampai saat ini sebagian besar energi yang dihasilkan dan digunakan berasal dari fosil yaitu sebesar $95 \%$ dari total bauran energi ${ }^{1-3}$. Dengan tingkat pertumbuhan ekonomi yang stabil dan kuat dalam beberapa tahun terakhir, permintaan energi akan terus meningkat. Tingkat ketergantungan yang tinggi terhadap energi fosil yang jumlahnya relatif terbatas dapat memicu krisis energi di negeri ini. Oleh karena itu masalah energi akan terus menjadi perhatian utama pemerintah di masa mendatang apalagi dengan meningkatnya masalah dampak lingkungan akibat pembakaran energi fosil untuk berbagai kegiatan sosialekonomi nasional $\mathrm{l}^{2,5,7,8}$.

Energi Terbarukan merupakan salah satu sumber energi yang dapat memenuhi kebutuhan energi dan menyumbang kepada bauran energi nasional dan membantu usaha mitigasi dampak perubahan iklim global. Sumber energi ini digunakan hampir di seluruh dunia yang telah memanfaatkan energi terbarukan sebagai sumber energi strategis untuk mengantisipasi krisis energi ${ }^{9-}$ 12

Elektrolisis air adalah peristiwa penguraian senyawa air $\left(\mathrm{H}_{2} \mathrm{O}\right)$ menjadi gas gas hidrogen $\left(\mathrm{H}_{2}\right)$ dan oksigen $\left(\mathrm{O}_{2}\right)$ dengan menggunakan arus listrik yang melalui air tersebut. $\mathrm{Gas}_{2}$ sangat pontensial digunakan sebagai sumber energi karena sifatnya yang ramah lingkungan.

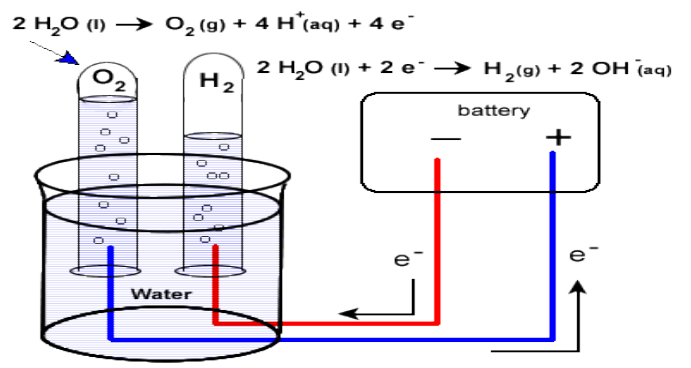

Gambar. 1. Proses hidrolisi air dan hidorogen 
Sel Elektrolisis adalah sel yang menggunakan arus listrik untuk menghasilkan reaksi redoks yang diinginkan dan digunakan secara luas di dalam masyarakat kita. Baterai aki yang dapat diisi ulang merupakan salah satu contoh aplikasi sel elektrolisis dalam kehidupan sehari-hari. Air $\left(\mathrm{H}_{2} \mathrm{O}\right)$ dapat diuraikan dengan menggunakan listrik dalam sel elektrolisis. Proses ini akan mengurai air menjadi unsur-unsur pembentuknya ${ }^{4,7,9,14}$.

Elektroda berperan sebagai tempat berlangsungnya reaksi. Reaksi reduksi berlangsung di katoda, sedangkan reaksi oksidasi berlangsung di anoda. Kutub negatif sumber arus mengarah pada katoda (sebab memerlukan elektron) dan kutub positif sumber arus tentunya mengarah pada anoda. Akibatnya, katoda bermuatan negatif dan menarik kation-kation yang akan tereduksi menjadi endapan logam. Sebaliknya, anoda bermuatan positif dan menarik anion-anion yang akan teroksidasi menjadi gas. Terlihat jelas bahwa tujuan elektrolisis adalah untuk mendapatkan endapan logam di katoda dan gas di anoda ${ }^{5,7}$.

Penelitian ini penting untuk dilakukan mengingat hidrogen merupakan gas yang paling mudah terbakar dan mudah meledak di udara terutama ketika bereaksi dengan oksidan. Pada suhu tinggi gas ini tergolong gas yang sangat reaktif. Pada proses produksinya air merupakan bahan utama untuk menghasilkan gas hidrogen. Oleh karena itu monitoring suhu, jumlah gas dan level yang tepat sangatlah dibutuhkan untuk proses produksi gas hidrogen ${ }^{2,8}$.

\section{Penggunaan Katalisator}

Senyawa-senyawa seperti asam, basa dan garam yang dapat menghantarkan arus listrik dapat digunakan dalam proses elektrolisis. Penggunaan senyawa-senyawa tersebutberfungsi mempermudah proses penguraian air menjadi hidrogen dan oksigenkarena ion-ion katalisator mampumempengaruhi kesetabilan molekul air menjadi menjadi ion $\mathrm{H}+$ dan $\mathrm{OH}$ yang lebih mudah di elektrolisis karena terjadi penurunan energi pengaktifan. Pada umumnya proses elektrolisis yang dilakukanuntuk menghasilkangas oksigen dan gas hidrogen menggunakanlarutan alkali. Larutan alkali yang umum digunakan adalah larutan $\mathrm{NaOH}$ dan $\mathrm{KOH}$. Larutan tersebut merupakan elektrolit kuat yang dapat menghantarkan arus listrik dengan baik. Secarateoritis, pemberian potensial energi lebih dari $5 \mathrm{~V}$ akan menghasilkan gas oksigen, gas hidrogen dan logam kalium $3,9,11,13$.

ACS712 20A adalah sensor arus yang bekerja berdasarkan efek medan. Sensor arus ini dapat digunakan untuk mengukur arus AC atau DC. Modul sensor ini telah dilengkapi dengan rangkaian penguat operasional, sehingga sensitivitas pengukuran arusnya meningkat dan dapat mengukur perubahan arus yang kecil. Sensor ini digunakan pada aplikasi-aplikasi di bidang industri, komersial, maupun komunikasi. Contoh aplikasinya antara lain untuk sensor kontrol motor, deteksi dan manajemen penggunaan daya, sensor untuk catu daya tersaklar, sensor proteksi terhadap arus lebih, dan lain sebagainya.

Tujuan khusus dari penelitian ini adalah melakukan control arus dan monitoring terhadap proses produksi gas hidrogen (H2) dengan metode elektrolisis air. perencanaan sensor dan system monitoring yang meliputi skma dan sfesifikasi khusus meliputi desain alat elektrolisis air, perancangan arduino, serta perencanaan program HMI dengan aplikasi Labview ${ }^{6}$.

\section{METODE PENELITIAN}

Penelitian ini

dilakukan

dilaboratorium teknologi elektromemedis STIKES Bainalita Sudama dan Laborium Teknologi Elektromedis USM-Indonesia. Adapun alat yang digunakan adalah box control, alat elektrolisis secara lengkap, katalisator soda api, rangkaian alat port arduino UNO, sensor arus $100 \mathrm{mV} /$ Ampere, Port Adc mikrokontroler dan analisis data menggunakan data Origin versi 6.0. 


\section{HASIL DAN PEMBAHSANAN}

Penelitian ini dilakukan dengan menggunakan sensor TGS 821 yang berfungsi untuk mendeteksi $\mathrm{H}_{2}$ yang akan keuar dari jalur yang sudah disediakan dan akan terbaca oleh TGS 821. Hasil yang terbaca pada TGS 821 akan dihubungkan ke PC dan akan dibaca pada tampilan akuisi dalam bentuk data microsoft excel. Data program pada layar dapat dilihat pada gambar berikut ini:

void setup () \{

Serial.begin(9600); \}

void loop () \{

int sensorHidrogen $=$ analogRead(A0);

Serial.printIn(sensorHidrogen);

Gambar.2. tampilan layar pada PC

Dalam penelitian ini proses dilakukan dalam rentang waktu yang ditentukan sesuai dengan kebutuhan selama 3 jam pada setiap selang waktu 10 sampai 12 detik. Dalam penelitian yang dilakukan sampel dibagai kedalam 4 bagian yang ditentukan nilai minimum dan maksimum dengan label sampel A, B, C dan $\mathrm{D}$ dengan pengulangan dilakukan sebanyak tiga kali dengan rentang arus yang digunakan $6 \mathrm{~V}, 7 \mathrm{~V}$ dan $8 \mathrm{~V}$.

Hasil penelitian dapat dilihat pada tabel. 1 dibawah ini:

\begin{tabular}{|c|c|c|c|c|}
\hline No & $\begin{array}{c}\text { Kode } \\
\text { Sampel }\end{array}$ & Suhu ${ }^{\mathbf{0}} \mathbf{C}$ & Kadar $\mathbf{O}_{\mathbf{2}}$ & Kadar $\mathbf{H}_{\mathbf{2}}$ \\
\hline 1 & $\mathrm{~A}$ & 30 & 13.14 & 29.05 \\
\hline 2 & $\mathrm{~B}$ & 30 & 13.35 & 29.08 \\
\hline 3 & $\mathrm{C}$ & 32 & 13.12 & 29.10 \\
\hline 4 & $\mathrm{D}$ & 32 & 13.23 & 29.23 \\
\hline & Rata-rata & 31 & 13.21 & 29.1 \\
\hline
\end{tabular}

Data grafik hasil pengujian dapat dilihat pada tabel berikut ini:

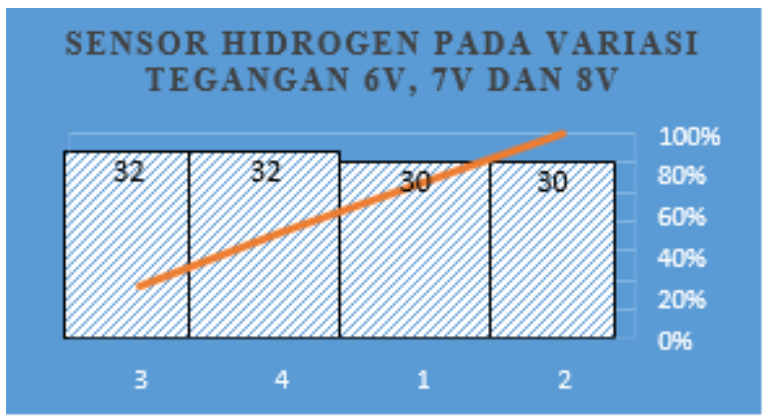

Universitas Sari Mutiara Indonesia

DOI: https://doi.org/10.51544/jalm.v6i2.2233
Pengujian pada Sensor Oksigen.

Penelitian dilakukan dengan merangkai rangkai alat dengan menghubungkan ke oksigen hasil penelitian pada pembacaan oksigen dapat dilihat pada tebel dibawah ini:

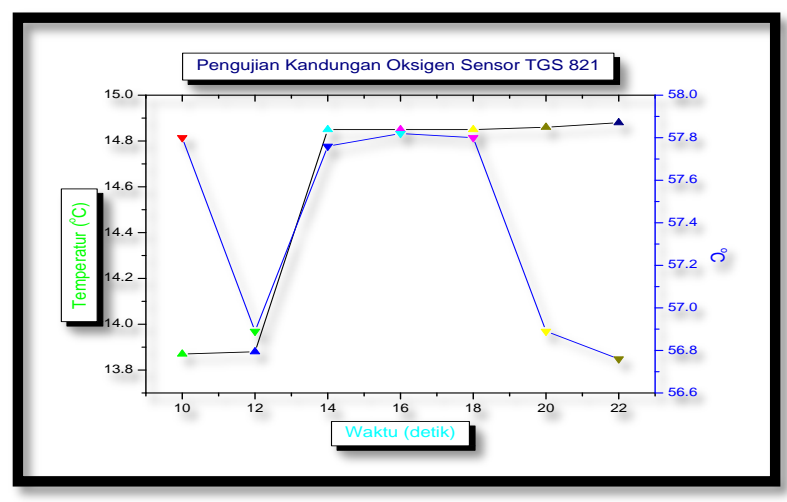

Gambar 2. Data hasil pengujian Oksigen.

Tabel 2. Data pengujian sensor hidrogen dan Oksigen

\begin{tabular}{|c|c|c|c|c|}
\hline Sampel & $\begin{array}{c}\text { Waktu } \\
(\text { detik) }\end{array}$ & $\begin{array}{c}\text { Temper } \\
\text { atur } \\
\left({ }^{\mathbf{0}} \mathbf{C}\right)\end{array}$ & $\begin{array}{c}\text { Jumlah } \\
\mathbf{O}_{\mathbf{2}}(\boldsymbol{\%})\end{array}$ & $\begin{array}{c}\text { Jumlah } \\
\mathbf{H}_{\mathbf{2}}(\boldsymbol{\%})\end{array}$ \\
\hline 1 & 10 & 30 & 13.87 & 57.80 \\
\hline 2 & 12 & 32 & 13.88 & 56.89 \\
\hline 3 & 14 & 31 & 14.85 & 57.76 \\
\hline 4 & 16 & 30 & 14.85 & 57.82 \\
\hline 5 & 18 & 32 & 14.85 & 57.80 \\
\hline 6 & 20 & 31 & 14.86 & 56.89 \\
\hline 7 & 22 & 30 & 14.88 & 56.76 \\
\hline
\end{tabular}

Data pengujian sensor hidrogen terhadap kandungan oksigen yang terkandung dalam sampel yang dilakukan pada proses hidrolisis

$$
2 \mathrm{H}_{2} \mathrm{O}(l) \rightarrow 2 \mathrm{H}_{2}(g)+\mathrm{O}_{2}(g)
$$

$\mathrm{H}_{2} \mathrm{O}$ dalam penelitian dilakukan dengan menggunakan penyaring sensor berfungsi untuk menyaring serapan yang akan diberikan (filter) dalam penelitian ini menggunakan tiga buah filter dengan kuat arus yang diberikan sebesar $8 \mathrm{~V}, 9 \mathrm{~V}$ dan $10 \mathrm{~V}$.

Tabel 3. Data hasil pengujian jumlah hidrogen dengan kuat arus $8 \mathrm{~V}, 9 \mathrm{~V}, 10 \mathrm{~V}, 11 \mathrm{~V}$ dan $12 \mathrm{~V}$.

\begin{tabular}{|c|c|c|c|c|}
\hline No & \multirow{2}{*}{$\begin{array}{c}\text { Kuata } \\
\text { Sampel }\end{array}$} & \multicolumn{3}{|c|}{ Filter (ppm) } \\
\cline { 3 - 5 } & (Volt) & & $\mathbf{1}$ & $\mathbf{3}$ \\
\hline 1 & 8 & 250,31 & 400,24 & 132,60 \\
\hline
\end{tabular}




\begin{tabular}{|c|c|c|c|c|}
\hline 2 & 9 & 321,50 & 524,32 & 350.18 \\
\hline 3 & 10 & 926.34 & 970.13 & 916.78 \\
\hline 4 & 11 & 998.20 & 950.71 & 920.18 \\
\hline 5 & 12 & 778.62 & 520.31 & 350.61 \\
\hline
\end{tabular}

Dari hasil penelitian dapat dilihat bahwa, ada peningkatan tegangan pada prosen elektrosis dengan peningkatan konsentrasi hidtrogen. Dari hasil penelitian ini dapat disimpulkan bahwa kuat arus yang tinggi jika diberikan pada proses elektrolisis akan terjadi

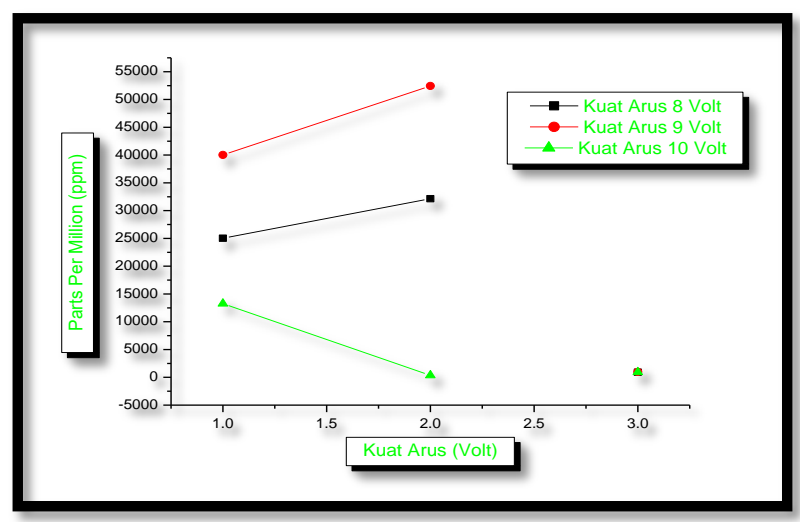

Gambar 3. Data kuat arus yang diberikan pada proses elektrolisis

pemecahan Hidrogen dan Oksigen dengan menguarai derajat ionisasi sehigga terpisah anatar ion hidtrogen dan oksigen dan pemecahan berlangsung semakin besar jika arus yang diberikan semakin besar pula dan tertinggi pada $12 \mathrm{~V}$. Pada proses tersebut pemutusan ikatan semakin cepat terjadi sehingga pada pembacaan semakin tinggi pada kandungan oksigen dan hidrogen. Dalam penelitin ini hidrgen yang dihasilkan akan melewati filter pada bagian 1 hingga 3 tujuan penggunaan filter tersebut adalah untuk mendapatkan hasil yang lebih baik pada pembacaan alat.

Elektrolisis air adalah peristiwa penguraian senyawa air (H2O) menjadi oksigen $(\mathrm{O} 2)$ dan hidrogen gas $(\mathrm{H} 2)$ dengan menggunakan arus listrik yang melalui air tersebut. Pada katode, dua molekul air bereaksi dengan menangkap dua elektron, tereduksi menjadi gas $\mathrm{H} 2$ dan ion hidrokida $(\mathrm{OH}-)$. Sementara itu pada anode, dua molekul air lain terurai menjadi gas oksigen $(\mathrm{O} 2)$, melepaskan 4 ion $\mathrm{H}+$ serta mengalirkan elektron ke katode. Ion $\mathrm{H}+$ dan $\mathrm{OH}-$ mengalami netralisasi sehingga terbentuk kembali beberapa molekul air. Reaksi keseluruhan yang setara dari elektrolisis air dapat dituliskan sebagai berikut.

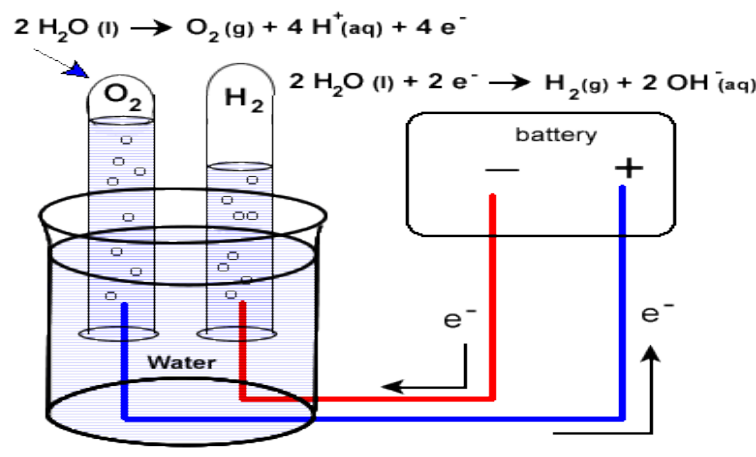

Gas hidrogen dan oksigen yang dihasilkan dari reaksi ini membentuk gelembung pada elektrode dan dapat dikumpulkan. Prinsip ini kemudian dimanfaatkan untuk menghasilkan hidrogen dan hidrogen peroksida (H2O2) yang dapat digunakan sebagai bahan bakar kendaraan hidrogen.

\section{KESIMPULAN}

Dari penelitian yang dilakukan dapat disimpulkan bahwa alat yang digunakan mampu mendetiksi gas hidrogen dengan baik dan dihasilkan data yang bisa dibaca pada PC dengan metode hidrolisi dalam penelitian dapat diketahui bahwa semakin tinggi kuat arus yang diberikan maka semakin tinggi juga kadungan oksigen dan hidrogen yang diberikan dan maksimal pada 12 volt yang mengakibat proses inisasi pada ion hidrogen dan oksigen semakin cepat bergerak bebas pendeteksian ini terlihat dengan meningkatnya jumlah yang diproleh pada filter yang dihasilkan dan dibaca pada PC. Dalam prosesenya gas hidrogen dapat dihasilkan dari hidrolisis dengan menggunakan TGS 821 dan DAC serta dihubungkan pada perangkat $\mathrm{PC}$ dalam proses penelitian ini besar arus yang digunakan adalah $8 \mathrm{~V}, 9 \mathrm{~V}, 10 \mathrm{~V}, 11 \mathrm{~V}$ dan $12 \mathrm{~V}$. hasil penelitian menunjukkan adanya peningkat jumlah hidrogen yang dihasilkan sebanding dengan peningkatan arus yang diberikan dan maksimum pada kuat arus 12 volt. Jumlah 
hidrogen maksim pada 998,20 ppm dan paling rendah pada $131,60 \mathrm{ppm}$.

\section{UCAPAN TERIMAKASIH}

Peneliti mengucapakan terimakasih kepada Direktorat Riset dan Pengabdian Masyarakat Deputi Bidang Penguatan Riset dan Pengembangan Kementerian Riset dan Teknologi/ Badan Riset dan Inovasi Nasional, Kemendikbud Ristek yang telah memeberikan pendanaan Penelitian Dosen Pemula tahun 2020 pelaksanaan 2021 dan Kepada STIKES Binalita Sudama tempat peneliti mengabdikan diri.

\section{DAFTARA PUSTAKA}

Sulton Ali, Muhammad, "Hydro Fuel Cell (Kapal Bertenaga Gas HHO dengan Metode Elektrolisis Air untuk Efisiensi Bahan Bakar BBM yang Berguna bagi Kesejahteraan Nelayan Indonesia”, LKTI, Surabaya, 2018

Winoto, Ardi, "Mikrokontroler AVR ATmega8/16/32/8535.'Informatika, Bandung, 2015

Louise, I.S.Y, Dewi, Y., \& Heru P.A. (2015). Pemecahan Molekul Air Dengan Media Tepung Umbi Dahlia (Dahlia Pinata). Jurnal Sains Dasar, 2, 173-178.

Marlina, E., Slamet, W., \& Lilis, Y. (2013). Produksi Gas Brown's Gas Hasil Elektrolisis $\mathrm{H} 2 \mathrm{O}$ denganKatalis NaHCO3. Jurnal Rekayasa Mesin, 4, 5357

Wahyono, I., Salam, R., Dimyati, et al. (2015). Karakterisasi Struktur Mikro Menggunakan SEM dan XRD pada Ketahanan Korosi Baja Komersial SS430 dan Baja Non Komersial F1. Disajikan pada Seminar Nasional XI SDM Teknologi Nuklir, di UPN "V" Yogyakarta.

Fahrudin, A. (2015). Pengaruh Jarak Antar Plat pada Generator HHO Model Wet Cell terhadap Debitdan Efisiensi. Jurnal SAINT EK, 12, 37- 41Louise, I.S.Y. (2014). Stainless steel/Fe-Co-Ni sebagai Elektro Katalis pada Reaksi Evolusi Hidrogen. Abstrak Disertasi
Louise, I.S.Y. (2014). Stainless steel/FeCo-Ni sebagai Elektro Katalis pada Reaksi Evolusi Hidrogen. Abstrak Disertasi.

Louise, I.S.Y. (November, 2010). Perilaku Sel Elektrolisis Air dengan Elektrode Stainless steel. Makalah disajikan dalam Seminar Nasional Kimia, di Universitas Negeri Yogyakarta.

Mahreni,\& Ade, I. (2011). Pengembangan Teknologi Bersih Berbasis Hidrogen Menggunakan Sumber Daya Alam Indonesia. Makalah disajikan dalam Seminar Nasional Teknik Kimia "Kejuangan", di FTI UPN "V" Yogyakarta.

Afrizal, M.A. 2018. Rancang Bangun Rumah Pintar Berbasis IOT (Internet of Things) Sebagai Media Pembelajaran pada Mata Pelajaran pemrograman, Mikroprosesor dan Mikrokontroller di SMKN2 Surabaya. Jurnal Pendidikan Teknik Elektro. Vol.7, No.1, pp.79-86.

Rahmawati, Novi, Dony, Novria. 2014. "Pembuatan Pupuk Organik Berbahan Sampah Organik Rumah Tangga Dengan Penambahan Aktivator Em4 di Daerah Kayu Tangi”. Fakultas Keguruan dan Ilmu Pendidikan Universitas Islam Kalimantan MAB Banjarmasin.

Palar, H. 1994. Pencemaran dan Toksikologi Logam Berat. Jakarta: Rineka Cipta

Siswanto, A 1991. Toksikologi Industri. Surabaya: Balai Hiperkes dan Keselamatan Depnaker jatim

Adryanto. 2005.Deteksi Pencemaran Timah Hitam $(\mathrm{Pb})$ dalam Darah, Masyarakay yang Terpajan Timbal (Plumbum), Jurnal Kesehatan Lingkungan Vol-2/No.1 